\title{
IMMUNO-ELECTROPHORETIC ANALYSIS OF HUMAN CERVICAL MUCUS AND SEMINAL PLASMA WITH AN ANTISERUM TO CERVICAL MUCUS
}

\author{
SALLY R. De FAZIO ANd M. M. KETGHEL \\ Department of Physiology, Tufts University School of Medicine, \\ Boston, Massachusetts 02111, U.S.A.
}

(Received 7th February 1970, revised 13th October 1970)

\begin{abstract}
Summary. Rabbit antibody to human cervical mucus was used in the immuno-electrophoretic analysis of cervical mucus, seminal plasma and blood serum. Eleven antigens were found in cervical mucus, but no more than nine in any one sample. One post-coital sample of cervical mucus in the pool used to produce the antiserum contained an antigen, thought to be prostatic acid phosphatase, derived from the semen contamination. Three antigens appeared specific for cervical mucus, being absent from seminal plasma and serum. Another two antigens were shared with seminal plasma and serum, two were shared with seminal plasma only, and a further two were shared with serum only.

Two of the cervical mucus antigens were identified as immunoglobulin-G and albumin, and another two were believed to be transferrin and $\alpha-1$ antitrypsin.
\end{abstract}

\section{INTRODUCTION}

Human seminal plasma contains many proteins, only some of which are also found in the blood (Quinlivan, 1969). These proteins may be highly antigenic when injected into animals of a different species, or, when administered with Freund's adjuvant, to animals of the same species. However, female animals apparently do not exhibit a circulating antibody response after injection of homologous seminal plasma when no adjuvant is used (Weil \& Finkler, 1959; Menzoian \& Ketchel, 1966). Although women are frequently exposed to the seminal plasma of men of different genetic background, serious immunological reaction to seminal plasma seems to be limited to the possible production of infertility in a small percentage of women (Israelstam, 1969). Recent evidence, however, indicates that the frequency of such sensitization may have been overestimated, since the anti-sperm factors present in the sera of some women do not appear to be immunoglobulins (Boettcher \& Kay, 1969).

As an explanation for the failure of female animals to develop an immune response to injected seminal plasma, Menzoian \& Ketchel (1966) suggested that since the male and female accessory glands have a common embryological origin, it may be that the female accessory glands produce the same proteins that their embryological homologues produce in the male. The female would 
then fail to recognize the proteins of seminal plasma as 'foreign'. They were able to demonstrate that the bovine female reproductive tract does share with bovine seminal plasma at least one protein which is not found in blood serum or certain other tissues.

In a previous study, De Fazio, Lewis \& Ketchel (1969) examined the hypothesis that seminal plasma from different men must contain essentially the same antigens, since, if there were much variation among men, women could not possibly fail to recognize as foreign some of the antigens of different men. Our results indicated that, while the major antigens occurred in the seminal plasma of all subjects studied, minor but distinct differences in antigenic components do occur.

The present study was undertaken to extend our studies on the nature of the antigens contained in reproductive tract secretions to human cervical mucus. Rao \& Sadri (1959), utilizing an antiserum against seminal plasma, analysed cervical mucus and seminal plasma by immunodiffusion. They reported that these fluids shared four components, three of which were also found to occur in blood serum. Immuno-electrophoretic analysis of cervical mucus has been confined to the serum proteins which it contains (Schumacher, 1968). Heinen, Keutel \& Ott (1965) reported that they had been unable to produce an antiserum directed against cervical mucus. In the present study, an antiserum directed against cervical mucus was used in conjunction with antisera against seminal plasma and blood serum, permitting an immuno-electrophoretic comparison of cervical mucus antigens with the antigens of seminal plasma and blood serum.

\section{METHODS AND MATERIALS}

Cervical mucus samples were obtained from women attending the Pratt Diagnostic Clinic, Tufts-New England Medical Center. Except for a post-menopausal woman who was undergoing treatment with methyltestosterone, patients were of reproductive age, and all patients were free of gross cervicitis. A vacuum pump was used to aspirate the mucus into polypropylene pipettes. Immediately after collection, the samples were refrigerated, and within a few hours were frozen and stored at $-20^{\circ} \mathrm{C}$. Separation from the cellular and microbial débris by centrifugation was prevented by the high viscosity and small volumes of the mucus samples.

Eight healthy young men provided semen samples which were immediately centrifuged to remove spermatozoa and detritus, and then stored at $-20^{\circ} \mathrm{C}$.

Human serum was decanted from clotted blood and stored at $-20^{\circ} \mathrm{C}$.

Antiserum to human cervical mucus was prepared in two albino rabbits. Once a week for 3 weeks each rabbit was injected intramuscularly with $0.25 \mathrm{ml}$ pooled human cervical mucus emulsified in $0.5 \mathrm{ml}$ Freund's complete adjuvant. Two weeks later, $0.25 \mathrm{ml}$ mucus without adjuvant was injected and 4 days after the last injection, the rabbits were bled. Two months later, each rabbit was again injected with $0.25 \mathrm{ml}$ cervical mucus without adjuvant and 5 days later, the rabbits were bled again. Sera obtained from these bleedings were not pooled since they differed widely in quality. 
The hormonal status of the women providing the cervical mucus samples is indicated in Table 1. At the time of injection into rabbits, we believed that all the samples collected were obtained from women who had not had intercourse for at least $24 \mathrm{hr}$ before sample collection, but subsequent data, confirmed by a re-examination of clinical records, revealed that one sample was contaminated

TABLE 1

PREGIPITIN BANDS OF HUMAN GERVICAL MUGUS SAMPLES DEMONSTRATED WITH ANTISERUM TO GERVIGAL MUGUS

\begin{tabular}{|c|c|c|c|c|c|c|c|c|c|c|}
\hline \multirow{2}{*}{$\begin{array}{c}\text { Sample } \\
\text { No. }\end{array}$} & \multicolumn{10}{|c|}{ Band No. } \\
\hline & $I$ & $I I$ & III & $I V$ & $V$ & $V I$ & $V I I(V I I I \dagger)$ & $I X$ & $x$ & $X I$ \\
\hline & \multicolumn{10}{|c|}{ Ovulation, no hormonal treatment } \\
\hline $2 *$ & + & & & & + & & + & + & + & + \\
\hline $7^{*}$ & & & & + & + & & + & & + & + \\
\hline $9^{*}$ & + & & & + & + & + & + & + & + & + \\
\hline $10^{*}$ & & & & + & + & + & + & & + & \\
\hline $11^{*}$ & & & & + & + & + & + & & + & + \\
\hline $13^{*}$ & + & & & & + & & + & + & + & + \\
\hline $41 *$ & + & & & + & + & & + & + & + & \\
\hline \multicolumn{11}{|c|}{ Day 8 of menstrual cycle, no hormonal treatment ${ }^{+}+$} \\
\hline 55 & + & \multirow{2}{*}{\multicolumn{7}{|c|}{$\begin{array}{c}+ \\
\text { Day } 17 \text { of menstrual cycle, no hormonal treatment } \\
+++++\end{array}$}} & + & + \\
\hline $61 \ddagger$ & + & & & & & & & & + & + \\
\hline $3 *$ & + & & & + & & & + & + & + & \\
\hline $4^{*}$ & + & & & + & + & & + & + & + & + \\
\hline $5^{*}$ & + & & & + & & & + & & + & + \\
\hline $37^{*}$ & + & & & + & + & + & + & & + & + \\
\hline 50 & + & & & & & & + & & + & + \\
\hline $64 \ddagger$ & + & + & Cor & $\stackrel{+}{+}$ & $\stackrel{+}{c o n}$ & cept & $\stackrel{+}{+}$ (Orthonovur & & + & + \\
\hline 60 & + & & & ulati & gor & lotrc & hin stimulation & + & + & \\
\hline $14^{*}$ & & & & + & me & $\stackrel{+}{+}$ & $\stackrel{+}{y c l e, ~ o e s t r o g e n}$ & & + & + \\
\hline $46^{*}$ & + & & & & $\stackrel{+}{+}$ & . & $\stackrel{+}{+}$ & + & + & \\
\hline $33^{*}$ & + & & & + & , go & dotr & hin stimulatior & + & + & + \\
\hline $\begin{array}{l}51^{*} \\
53\end{array}$ & + & & $\stackrel{+}{+}$ & $\begin{array}{c}+ \\
\text { enope }\end{array}$ & al, $\mathrm{r}$ & thylt & $\stackrel{+}{+}$ & $\stackrel{+}{\operatorname{ment}}$ & + & + \\
\hline
\end{tabular}

* Samples used for immunization.

+ Band VIII is present in cervical mucus due to contamination with semen.

¥ Samples which were known to be free of semen.

with seminal plasma. Thus, the antiserum, although referred to here as anticervical mucus serum, was in reality directed against cervical mucus contaminated slightly with seminal plasma.

Antiserum to human seminal plasma was prepared in three albino rabbits. Samples from three men were pooled and $0.5 \mathrm{ml}$ seminal plasma emulsified with $0.5 \mathrm{ml}$ Freund's complete adjuvant was injected into each rabbit three times each week for 2 weeks. Two weeks later, $0.5 \mathrm{ml}$ seminal plasma without adjuvant was injected and 2 days later the rabbits were bled. Sera from these 
rabbits were carefully pooled to obtain an antiserum of the highest possible quality.

Antisera to whole human serum, human transferrin and $\alpha-1$ antitrypsin were obtained from Certified Blood Donors, Inc. (Berkingwerke).

Immuno-electrophoresis was performed according to the micromethod of Scheidegger (1955). Microscope slides were coated with $1 \%$ agarose in barbital buffer ( $\mathrm{pH} 8 \cdot 2$; ionic strength 0.025 ). Electrophoresis was carried out for $30 \mathrm{~min}$ at $34 \mathrm{~mA}$. Generally, $0.002 \mathrm{ml}$ of undiluted seminal plasma or blood serum or $0.006 \mathrm{ml}$ of cervical mucus was placed in the antigen well. Mincing the mucus with fine scissors allowed it to be drawn into capillary tubes for transfer to the well. Following electrophoresis, $0.1 \mathrm{ml}$ antiserum was placed in the trough, and the slides were placed in a moist chamber for $24 \mathrm{hr}$ to permit the development of precipitin bands. Slides were then washed overnight by agitation in saline, dried under filter paper, and stained. For protein staining, we utilized a stain composed of $0.1 \%$ amidoschwartz, $0.1 \%$ light green $\mathrm{SF}$, and $0.1 \%$ thiazine red $\mathrm{R}$ in $2 \%$ acetic acid.

Precipitation lines were stained by the periodic acid-Schiff method (Uriel, 1964) and by the Gomori method for acid phosphatase (Shulman, Mamrod, Gonder \& Soanes, 1964).

Absorption of anti-cervical mucus serum was performed by adding equal volumes of either human serum or seminal plasma to the antiserum, incubating for $18 \mathrm{hr}$ at $4^{\circ} \mathrm{G}$, and removing, by centrifugation, the precipitate that was formed.

\section{RESULTS}

A total of eleven antigens was demonstrated with anti-cervical mucus serum in the twenty-three mucus samples studied, although any one sample contained no more than nine of the components. Text-figure 1 is a composite diagram indicating the position and relative strength of each precipitin band formed by these cervical mucus samples. In an attempt to reveal antigens which might be present in concentrations which did not form a precipitate with the antiserum, further studies were carried out on five mucus samples with antiserum dilutions of $1 / 2,1 / 4,1 / 8$ and $1 / 16$.

The bands detected in each sample and the hormonal status of the patients providing the cervical mucus samples are recorded in Table 1. All of the samples, except the one obtained from a post-menopausal woman (Sample 53), contained Band $\mathrm{X}$, and about three out of four of the samples contained Bands I, IV, VII and XI. Bands II and III were each detected in only two samples.

Only one sample exhibited Band VIII. At the time this sample was received, it was believed to be free of seminal plasma and was included in the pool of samples utilized to develop the antisera in rabbits. Later investigation revealed that the sample had been taken post coitum. As seen in Text-fig. 1, Band VIII, as well as a number of other bands, occurs in seminal plasma. Previous studies in our laboratory had indicated that Band VIII in seminal plasma is the major band which exhibits the positive histochemical reaction for acid phosphatase described by Shulman et al. (1964). This activity is blocked by the addition of 
L-tartrate, an inhibitor of prostatic, but not erythrocytic, acid phosphatase (Abul-Fadl \& King, 1949). All cervical mucus samples were tested for acid phosphatase and only the post-coital sample showed activity, which was localized in Band VIII. When substrate was omitted from the incubation medium or tartrate added to it, no staining appeared. Thus, Band VIII, appearing only in this single sample of post-coital cervical mucus, seems identical to prostatic acid phosphatase. It seems reasonable to ascribe its presence in this sample to contamination with seminal plasma, though the possibility could not be eliminated that Band VIII is a normal component in the cervical mucus of this single patient among the twenty-three tested. Another sample of cervical mucus not contaminated with seminal plasma would have been useful in resolving this problem, but the patient was no longer available.

The results of a series of experiments to determine which antigens of cervical mucus also occur in blood serum and which also occur in seminal plasma are indicated in Text-fig. 2(a). Gervical mucus, known to be semen-free, was subjected to electrophoresis on a slide with two troughs. Anti-cervical mucus serum absorbed with blood serum was placed in one trough and anti-cervical

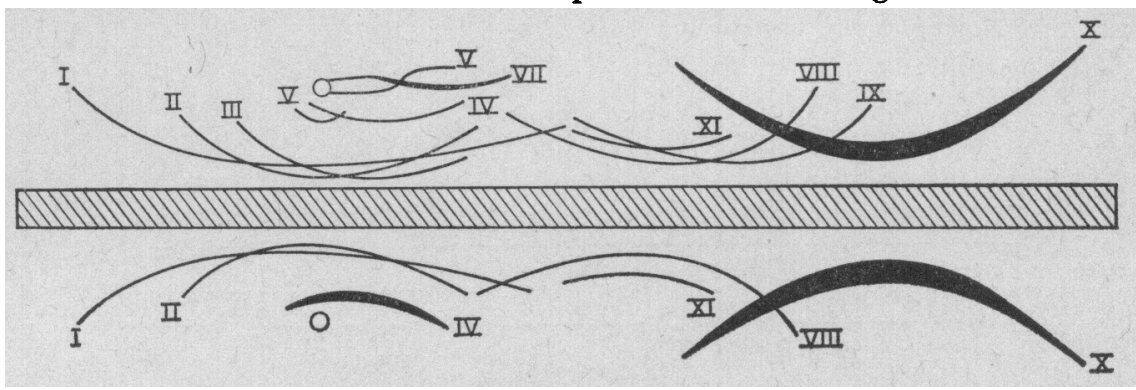

TEXT-FIG. 1. The location and relative prominence of all antigens observed in cervical mucus (upper well) and seminal plasma (lower well) using anti-cervical mucus serum (trough).

mucus serum absorbed with seminal plasma was placed in the other. Completeness of absorption of the anti-cervical mucus serum with blood serum or with seminal plasma was indicated by the absence of precipitin bands following the immuno-electrophoresis of blood serum or seminal plasma with the appropriate absorbed anti-cervical mucus serum. The results show that Bands II and IV represent antigens common to cervical mucus and seminal plasma but not to blood serum, while Bands III, V and VI appear specific for cervical mucus.

It may be observed in Text-fig. 2(a) that Bands II and IV are continuous with precipitin lines that extend the length of the slide. These lines were apparently formed by the reaction of excess seminal plasma antigens in the anticervical mucus serum absorbed with seminal plasma reacting with antibodies in the anti-cervical mucus serum absorbed with blood serum. In order to provide additional evidence that these bands are shared by cervical mucus and seminal plasma, but not by blood serum, a slide was prepared as described for the experiment, the results of which are shown in Text-fig. 2(a). Anti-cervical mucus serum absorbed with blood serum was added to one trough and anticervical mucus serum absorbed with seminal plasma to the other. Two additional wells were made between the troughs in the location of the precipitin 
lines which were continuous with Band IV (Text-fig. 2b). Blood serum was placed in one of these wells and seminal plasma in the other. Seminal plasma, but not blood serum, caused a deflection in the precipitin line continuous with Band IV, indicating that Band IV represents an antigen shared by cervical mucus and seminal plasma, but not by blood serum. Band IV had an electrophoretic mobility suggestive of lactoferrin, an iron-binding protein known to be

○

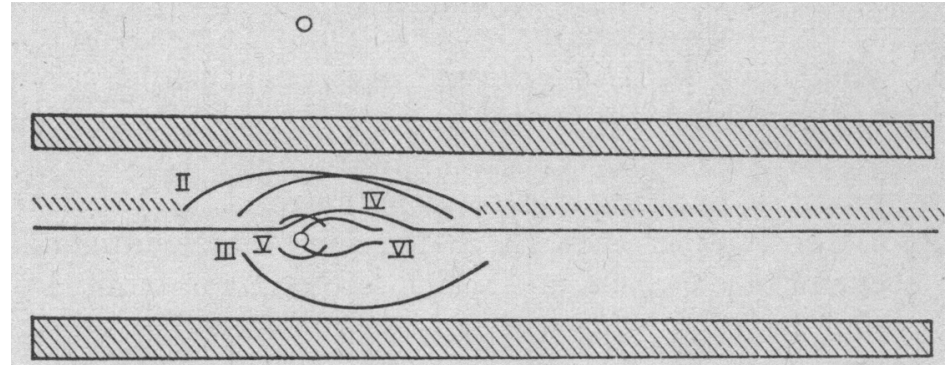

(a)

0

0

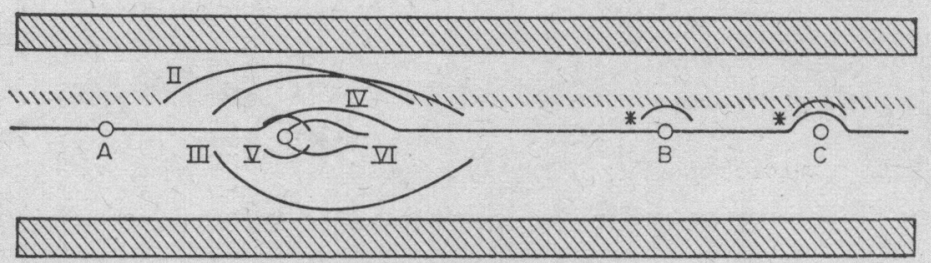

(b)

TEXT-FIG. 2. (a) The precipitin bands appearing when cervical mucus (central well) is allowed to react with anti-cervical mucus serum which had been absorbed with blood serum (upper trough) and the same antiserum absorbed with seminal plasma (lower trough). The upper well contained blood serum and the lower well contained seminal plasma. (b) A slide prepared similarly to that shown in (a). After electrophoresis, additional antigen wells were cut and filled with blood serum (A), human milk (B) and seminal plasma (C). Precipitin arcs caused by diffusion of antigen from these wells are marked with asterisks.

present in milk, cervical mucus, seminal plasma and a number of other secretions (Masson \& Heremans, 1966). Human milk, however, was not found to cause a deflection of the line associated with Band IV, and the precipitin line continuous with Band II was too diffuse to permit an analysis similar to that described for Band IV.

In an attempt to establish identity between antigens in cervical mucus and blood serum, cervical mucus was further subjected to electrophoresis between two troughs, to one of which was added an antiserum against human blood serum and to the other anti-cervical mucus serum. Bands I, VII, IX and X showed reactions of identity with the two antisera. From their shape and 
position, Bands $\mathrm{I}$ and $\mathrm{X}$ were identified as immuno-globulin $\mathrm{G}$ and albumin, respectively. The substitution of blood serum for cervical mucus confirmed this identification. Tentative identification of Band VII with transferrin and Band IX with $\alpha-1$ antitrypsin was made. Specific antisera to both of these serum proteins precipitated bands in the cervical mucus samples tested, although the bands were too indistinct to permit accurate judgement of identity with bands produced with antiserum to cervical mucus.

As stated earlier, Band VI does not appear to occur in seminal plasma or blood serum, but histochemical investigations of the antigens of cervical mucus revealed that Band VI gave a positive reaction with periodic acid-Schiff staining. Since seminal plasma also has a PAS-positive component of similar electrophoretic mobility (De Fazio \& Ketchel, unpublished observation), an experiment was carried out to determine whether the PAS-staining components of seminal plasma and cervical mucus were identical. However, PAS staining was demonstrated after the electrophoresis of seminal plasma without the

TABLE 2

SUMMARY OF EXPERIMENTAL DATA ON IMMUNO-ELEGTROPHORETIC BANDS OF HUMAN GERVICAL MUGUS

\begin{tabular}{|c|c|c|c|c|}
\hline \multirow[t]{2}{*}{ Band No. } & \multicolumn{2}{|c|}{ Occurrence in: } & \multirow[t]{2}{*}{ Identity } & \multirow[t]{2}{*}{ Histochemical reaction } \\
\hline & Serum & Seminal plasma & & \\
\hline I & + & + & Immuno-globulin G & \\
\hline II & - & + & & \\
\hline IV & - & + & & \\
\hline $\mathrm{V}$ & - & - & & \\
\hline VI & - & - & & PAS-positive \\
\hline VII & + & $\cdots^{*}$ & Transferrin (?) & \\
\hline VIII & - & + & $\begin{array}{l}\text { Contaminated from } \\
\text { seminal plasma }\end{array}$ & Acid phosphatase \\
\hline IX & + & —* & $\alpha-1$ antitrypsin (?) & \\
\hline $\begin{array}{l}\mathrm{X} \\
\mathrm{XI}\end{array}$ & $\pm(?)$ & $\begin{array}{l}+ \\
+\end{array}$ & Albumin & \\
\hline
\end{tabular}

* Transferrin and $\alpha-1$ antitrypsin can be demonstrated in seminal plasma using specific antisera to these proteins, but not using anti-cervical mucus serum.

addition of antiserum, even following overnight washing in saline. In contrast to this diffuse staining, a sharp PAS-positive band was seen following the immuno-electrophoresis of seminal plasma with anti-seminal plasma serum or cervical mucus with anti-cervical mucus serum. It therefore appears that the PAS-positive components are not identical in the seminal plasma and cervical mucus.

Band XI could be demonstrated when either cervical mucus or seminal plasma was precipitated with antiserum to cervical mucus. While it has not been possible to establish an identity between Band XI and any particular serum protein, this band was not demonstrated when the anti-cervical mucus serum was absorbed with blood serum. Band XI, therefore, is likely to be a serum protein that is found in both cervical mucus and seminal plasma.

A summary of the findings on each of the precipitin bands of human cervical mucus is presented in Table 2. 


\section{DISCUSSION}

This investigation has revealed that at least two components of human cervical mucus are immunologically identical to non-serum components of seminal plasma. The presence of these substances in the female secretion might account for their apparent lack of immunogenicity in women when encountered upon insemination. However, these components are not detectable in the cervical mucus of all women. Band IV was demonstrated in the cervical mucus of seventeen out of twenty-two women of reproductive age, while Band II appeared in only two cases. It is quite possible that these components are present in the cervical mucus of other individuals in concentrations too low to be detected by the available techniques.

The concept that certain proteins in seminal plasma are specific to the male reproductive tract requires an explanation of how females escape sensitization to these proteins as a result of their sexual activity. Our hypothesis that the proteins of seminal plasma do not sensitize the female because they occur in the secretions of the female reproductive tract is consistent with the data concerning some proteins, but not all of them. While other seminal plasma proteins may be present in cervical mucus in concentrations too small to be detected, it is also possible that these proteins may be found elsewhere in the female reproductive tract secretions and tissues.

Alternative explanations for the apparent failure of females to be sensitized to seminal plasma proteins should be examined. Women might normally lack the genetic capability to respond immunologically to the antigens of seminal plasma. Enzymes present in the female reproductive tract might degrade the seminal antigens before they could initiate an immune response. Proteolysis by the enzymes present in seminal plasma itself might also be involved. However, Menzoian \& Ketchel (1966) injected female rabbits with seminal plasma and were unable to detect an immunological response. Injection by-passes the proteolytic enzymes of the female reproductive tract and would be expected to dilute the seminal plasma to the point where proteolytic enzymes of the seminal plasma would not be significant. Moreover, partial degradation of seminal antigens might well 'unmask' additional antigenic determinants, increasing the possibility of sensitization.

Thus, several of the antigens of human seminal plasma may be found in the blood serum or cervical mucus of women. Since these antigens would not be recognized by the female as foreign, a partial explanation for the failure of females to develop an immune response after exposure to seminal plasma exists. A more complete explanation, involving additional seminal plasma antigens, might result from the examination of additional female tissues and secretions.

\section{ACKNOWLEDGMENTS}

The authors are grateful to Dr George W. Mitchell, Dr R. Nuran Turksoy and Dr Robert D. Kennison for procuring the samples of cervical mucus used in this study.

This work was supported by a National Institute of Health Training Grant, No. 5T01AM 5220-10. 


\section{REFERENCES}

ABul-FAdr, M. A. M. \& King, E. J. (1949) Properties of the acid phosphatase of erythrocytes and of the human prostatic gland. Biochem. 7. 45, 51.

BoetTcher, B. \& KAY, D. J. (1969) Fractionation of a human spermagglutinating serum. Nature, Lond., 223, 737.

De Fazio, S., Lewis, B. K. \& Ketchel, M. M. (1969) Antigenic variations in the seminal plasma of different men. F. Reprod. Fert. 20, 29.

Heinen, G., KeUtel, H. J. \& OTT, H. (1965) Immuno-elektrophoretische Untersuchungen des menschlichen Scheidenhalte unter physiologische und pathologischen Verhältnissen. Arch. Gynaek. 200, 259.

ISRAELSTAM, D. M. (1969) The incidence of spermagglutinating antibodies in the serum of infertile women. Fert. Steril. 20, 275.

Masson, P. L. \& Heremans, J. F. (1966) Studies on lactoferrin, the iron-binding protein of secretions. Protides biol. Fluids, 14, 115.

Menzotan, J. O. \& Ketchel, M. M. (1966) Immunological tolerance of the female to homologous seminal plasma protein. Nature, Lond. 211, 133.

Quinlivan, W. L. (1969) The specific antigens of human seminal plasma. Fert. Steril. 20, 58.

RAO, S. S. \& SADRI, K. K. (1959) Immunological studies with human semen and cervical mucus. VIth Int. Conf. plann. Parent., New Delhi, p. 313.

Scheidegger, J. J. (1955) Une micro-méthode de l'immuno-electrophorèse. Int. Archs Allergy appl. Immun. 7, 703.

Schumacher, G. F. B. (1968) Protein analysis of secretions of the female genital tract. Lying-in: The Fournal of Reproductive Medicine, 1,61 .

Shulman, S., Mamrod, L. Gonder, M. J. \& Soanes, W. A. (1964) The detection of prostatic acid phosphatase by antibody reactions in gel diffusion. F. Immun. 93, 474.

URIEL, J. (1964) Characterization reactions of proteins. In: Immunoelectrophoretic Analysis. Eds. P. Grabar and P. Burtin. Elsevier Publishing Company, Amsterdam.

Weil, A. J. \& Finkler, A. E. (1959) Isoantigenicity of rabbit semen. Proc. Soc. exp. Biol. Med. 102, 624. 